International Journal of Agriculture, Environment and Bioresearch

Vol. 5, No. 01; 2020

ISSN: $2456-8643$

\title{
PREGNANCY DETECTION IN RED SOKOTO GOAT
}

\author{
Umar Abubakar Abubakar ${ }^{1 *}$ and Atabo Shaibu Mohammed ${ }^{2}$ \\ ${ }^{1}$ Department of Veterinary Anatomy, Usmanu Danfodiyo University, Nigeria \\ ${ }^{2}$ Department of Animal Health and Production Technology, College of Agriculture and Animal Science Bakura, \\ Zamfara-Nigeria
}

https://doi.org/10.35410/IJAEB.2020.5463

Corresponding author: mohakosh@yahoo.com

\begin{abstract}
Fourty eight wasted fetuses and two day-old kids of the Red Sokoto goats obtained from Batta abattoir of Dange Shuni Local Government Area and the central abattoir of Sokoto State were used for this study. Each fetus and the day old kids were weighed and the crown vertebral rump length measured. 51 farmers were interviewed using questionnaire to determine their ability to detect pregnancy. The result of the work showed that body weight and CVRL increases with age and farmers can detect pregnancy at various stages using physical examination. Adequate breeding record keeping should be encouraged among farmers to help in detecting and ageing pregnancy in Red Sokoto goat.
\end{abstract}

Keywords: Body weight, CVRL, Farmers, Fetus, Pregnancy.

\section{INTRODUCTION}

Small ruminants are important domestic animals in tropical livestock production system. Goats are members of the family Bovidae and sub-family caprine (Ryder, 1984). Goats play an important role in the economy of many countries including Nigeria. The economic importance of these animals depends on the value of their produce or services which include among others meat, fiber and skin. Meat and milk obtained from these animals constitute the major source of animal protein and for greater part of the world population (Davendra and Mcleroy, 1982).

In Nigeria, goats are the most numerous of all types of livestock numbering about 27.6million (FOS, 1986). The goat population is made up of three breeds: the distinctive Maradi (Red Sokoto), the Sahel and the West African Dwarf goats. Of the three breeds of goats in Nigeria, the Red Sokoto is the most popular because of its sleek fleece structure (Oni, 2002).

Despite the economic importance of these animals, they are managed in a traditional production system that is characterized with low level of inputs, thus low productivity (Maigandi et al., 2001). The poor management practice is often associated with high reproductive wastage due to abortion and pre-weaning mortality (Osuagwuh, 1985; Maigandi et al., 2001). 
In addition, wastage of conceptus through slaughter of pregnant does is probably one of the most destructive practices man has ever used against his own production endeavors (Oni, 2002).

The challenge of precise pregnancy diagnosis in small ruminants remains a great concern to Veterinarians and farmers, especially in developing countries. The fact remains that avoidable losses can be achieved if the status of each doe is established before sale or slaughter (Umar $e t$ al., 2006). In developing countries, like Nigeria, pregnancy diagnosis, especially at early trimester still poses a great problem and presently most abattoirs in Nigeria do not have thorough pre-slaughter inspection regimes aimed at preventing pregnant animals from being slaughtered. There is also need to minimize fetal losses through the slaughter of pregnant and actively productive does and to establish some morphometric parameters for identifying the age of wasted fetuses.

The aim of this study is to determine the methods and problems of pregnancy diagnosis in the Red Sokoto goat among farmers.

\section{MATERIALS AND METHODS}

The study was conducted at Batta abattoir of Dange Shuni Local Governement area and the State central abattoir. Sokoto State is located in a semi-arid region of North-Western Nigeria (Adelana et al., 2003).Fourty eight wasted fetuses and two day-old kids of the Red Sokoto goats were obtained from Batta abattoir of Dange Shuni Local Government Area and the central abattoir of Sokoto State. The fetuses were obtained immediately after the pregnant does were slaughtered, and transported to the Veterinary Anatomy Laboratory, Usmanu Danfodiyo University Sokoto Nigeria. The day-old kids were obtained from local goat breeders. Each fetus was weighed using mettle digital weighing balance after severing the umbilical cord at the base. The body length (crown vertebral rump length) was measured along the vertebral column from the poll of the head to the base of the tail (Nwaogu and Okolie, 2006). The two kids were also treated similarly.

A number of farmers were interviewed using structural questionnaire to determine the ability to detect pregnancy. The sampling techniques adopted was purposeful method, in the sense that only the farmers found on a particular day were drawn into the sample. The sampling procedure was designed to sections. The first section is devoted to socioeconomic and demographic characteristics of the respondents. The variables considered include: age, marital status, occupation, educational qualification and possession of animals. Second section focused on the respondent's level of awareness on traditional methods of pregnancy diagnosis.

The data was analyzed using descriptive statistics (percentage and histogram) and ANOVA

\section{SECTION A}

\section{SOCIOECONOMIC AND DEMOGRAPHIC CHARACTERISTICS OF RESPONDENTS}

1. Either how old are you or your last birthday? Or (if respondent cannot answer) in which year were you born? 

a. (either write in Age)
b. (Or write in year born)

2. What is your marital status?
a. Single (Never married)
b. Married
c. Divorced
d. Separated
e. Widowed

3. What is your occupation?
a. Unemployed
b. Farming
[ ]
c. Butchering
[]
[ ]

4. What is your educational qualification?
a. Non-literate
[ ]
b. Literate in local (vernacular) language or religious text alone
c. Primary
d. Secondary
e. Diploma/NCE
[ ]
f. University first degree/HND
[]
[ ]

5. For how long have you been in your named occupation? Write in years

6. Do you have a trade Association?
a. Yes
[ ]
b. No
[ ]

\section{SECTION B}

\section{LEVEL OF AWARENESS ON PREGNANCY DIAGNOSIS METHODS}

7. How many animals do you have in your flock (Skip if the respondent is not a farmer)
a. Females
b. Males
[ ]
c. Total
[ ]
[ ]

8. How many of the animals do you sell/slaughter per day Males Females
a. $1-5$
[ ]
b. $6-10$
[ ]
[ ]
[] 

c. $11-15$
d. 16 and above
[ ]
[ ]
[ ]

9. Of all the animals you sell/slaughter how many are ? (Insert a or b)
a. Females
b. Males

10. What signs do you observe when an animal is pregnant?
a. Change on behavior of the animal
b. Increase in size and weight
c. Mammary development
d. Other, specify

11. At what age do Red Sokoto goat conceive?
a. 4 months
[ ]
b. One month
[ ]
c. Nine months
[ ]
d. One year
[ ]

12. Do you have any comment?

Thank you so much, your answers have been helpful, please be assured that they will remain confidential.

\section{RESULT}

Table 1: Range and Mean \pm STDEV of body weight and crown-rump length

\begin{tabular}{|c|c|c|c|}
\hline $\begin{array}{l}\text { Estimated fetal age } \\
\text { (weeks) }\end{array}$ & Sample Number (N) & $\mathrm{BW}(\mathrm{g})$ & CVRL (cm) \\
\hline Group 1 (6-7) & 18 & $\begin{array}{l}4.3-35.7 \\
(11.9 \pm 8.90)^{\mathrm{a}}\end{array}$ & $\begin{array}{l}3.5-9.5 \\
(6.22 \pm 18)^{\mathrm{a}}\end{array}$ \\
\hline Group 2 (8-9) & 12 & $\begin{array}{l}36.1-197.5 \\
(82.2 \pm 67.81)^{\mathrm{b}}\end{array}$ & $\begin{array}{l}10.3-16.7 \\
(13.41 \pm 12)^{a}\end{array}$ \\
\hline \multirow[t]{2}{*}{ Group 3 (10-11) } & 7 & $\begin{array}{l}191.1-361.7 \\
(285.2 \pm 86.16)^{\mathrm{c}}\end{array}$ & $\begin{array}{l}18.3-21.5 \\
(20.22 \pm 11)^{\mathrm{a}}\end{array}$ \\
\hline & & $\begin{array}{l}446.8-471.3 \\
(457.9 \pm 12.15)^{\mathrm{d}}\end{array}$ & $23.0-24.5$ \\
\hline
\end{tabular}


International Journal of Agriculture, Environment and Bioresearch

Vol. 5, No. 01; 2020

ISSN: $2456-8643$

\begin{tabular}{|llll|}
\hline Group 4 (12-13) & 5 & & $(23.30 \pm 22)^{\mathrm{a}}$ \\
Group 5 (14-15) & 4 & $(1070 \pm 122.46)^{\mathrm{e}}$ & $31.7-32.3$ \\
& & $1432.2-1800$ & $(31.8 \pm 11)^{\mathrm{a}}$ \\
Group 6 (16-17) & 2 & $(1616.1 \pm 260.07)^{\mathrm{f}}$ & $34.0-35$ \\
& & & $(34.5 \pm 0.70)^{\mathrm{b}}$ \\
Group 7 (Day old) & 2 & $(1504.0-1600$ & $36.0-37.4$ \\
\hline
\end{tabular}

Means with different superscript across a column differ significantly $(\mathrm{p}<0.05)$

Key: Body Weight (BW) Crown Vertebral Rump Length (CVRL)

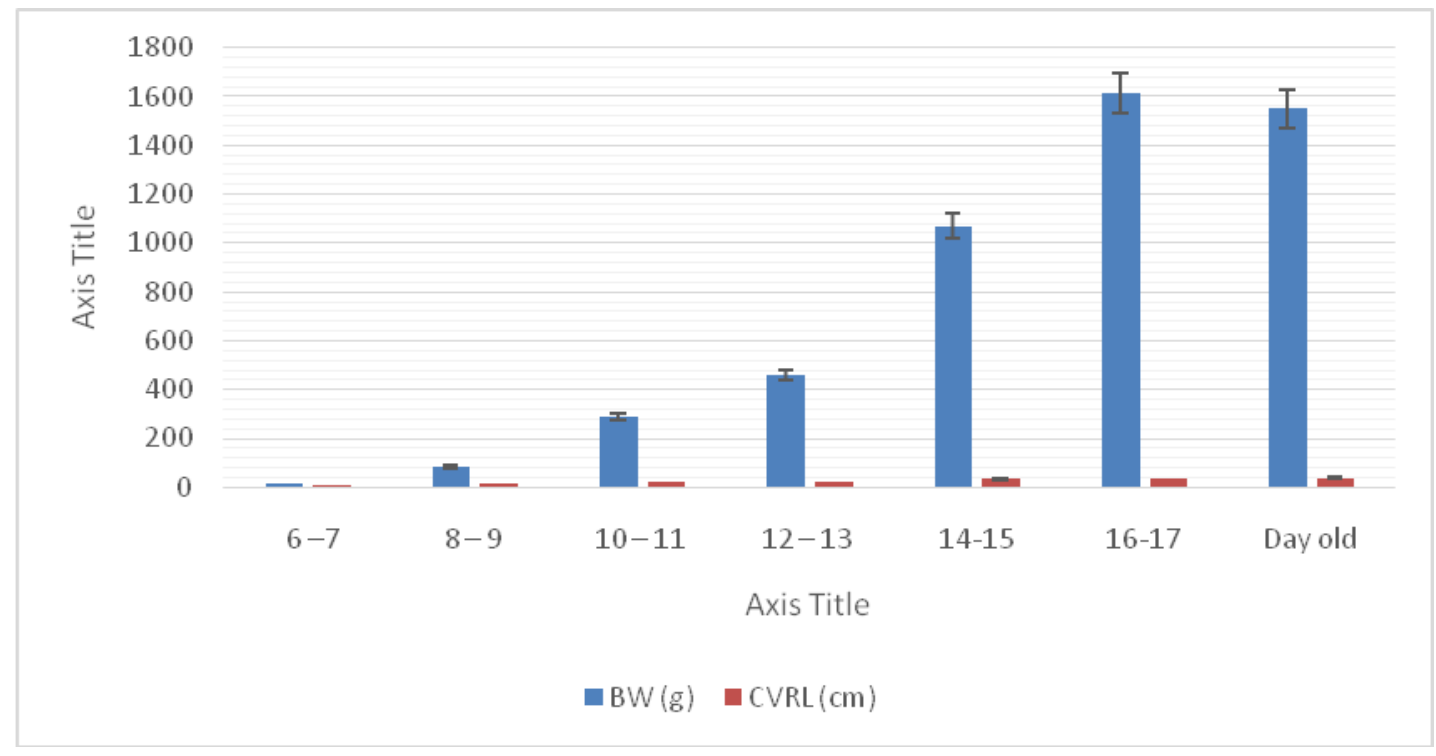

Figure 1: Range and Mean \pm STDEV of body weight and crown-rump length

Table 2: Range and Mean \pm STDEV of body weight and Crown Vertebral Rump Length across the three trimesters of pregnancy

\begin{tabular}{|llll|}
\hline Criteria & $1^{\text {st }}$ trimester & $2^{\text {nd }}$ trimester & $3^{\text {rd }}$ trimester \\
\hline CVRL $(\mathrm{cm})$ & $4.9-19$ & $20.6-24.6$ & $31.7-37.3$ \\
& $(10.0 \pm 12)^{\mathrm{a}}$ & $(21.2 \pm 08)^{\mathrm{b}}$ & $(33.3 \pm 40)^{\mathrm{b}}$ \\
\hline
\end{tabular}


International Journal of Agriculture, Environment and Bioresearch

Vol. 5, No. 01; 2020

ISSN: $2456-8643$



Means with different superscript across a row differ significantly $(\mathrm{p}<0.05)$

Key: Body Weight (BW) Crown Vertebral Rump Length (CVRL)

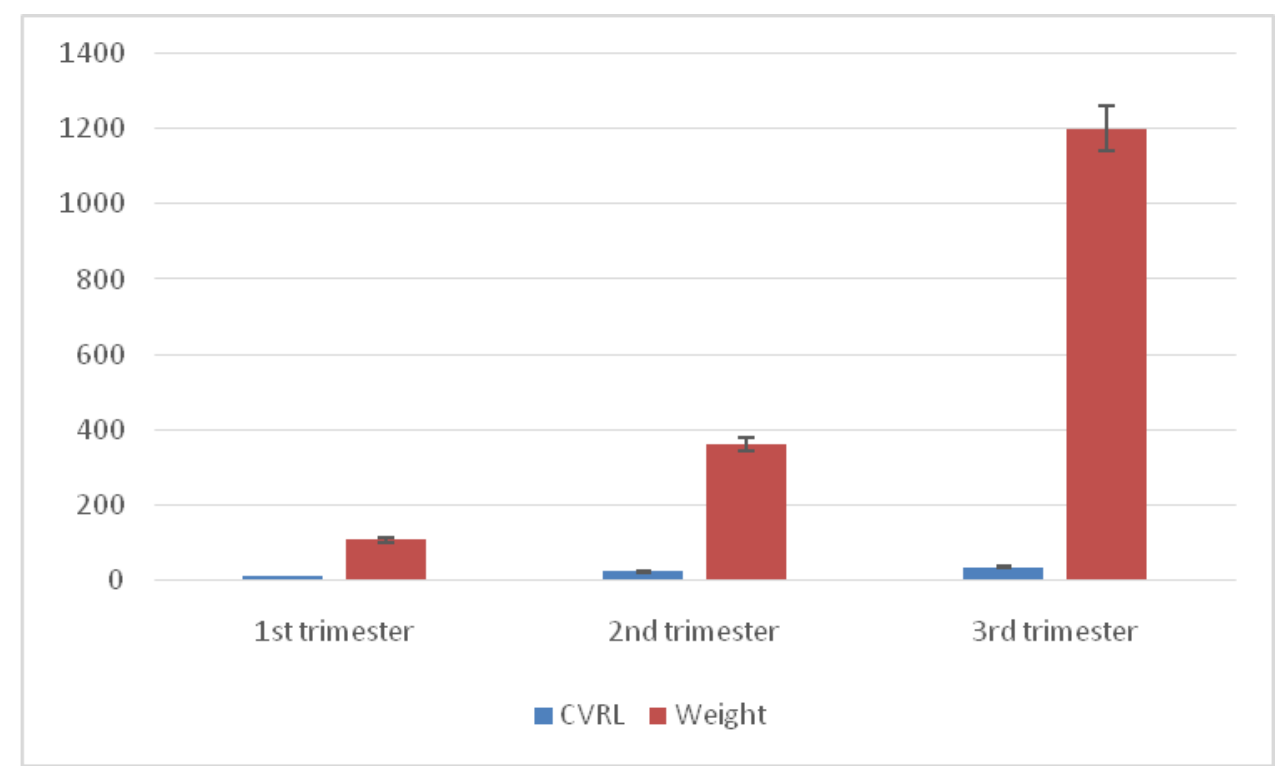

Figure 2: Range and Mean \pm STDEV of body weight and Crown Vertebral Rump Length across the three trimesters of pregnancy

Key: Body Weight (BW) Crown Vertebral Rump Length (CVRL)

\section{Pregnancy detection among farmers}

A total of 51 farmers responded to the questionnaire. All the farmers were married and number of Red Sokoto goats in their farms ranges from 7-40. The opinions of the farmers' respondents are summarized and presented in figure 3 . 


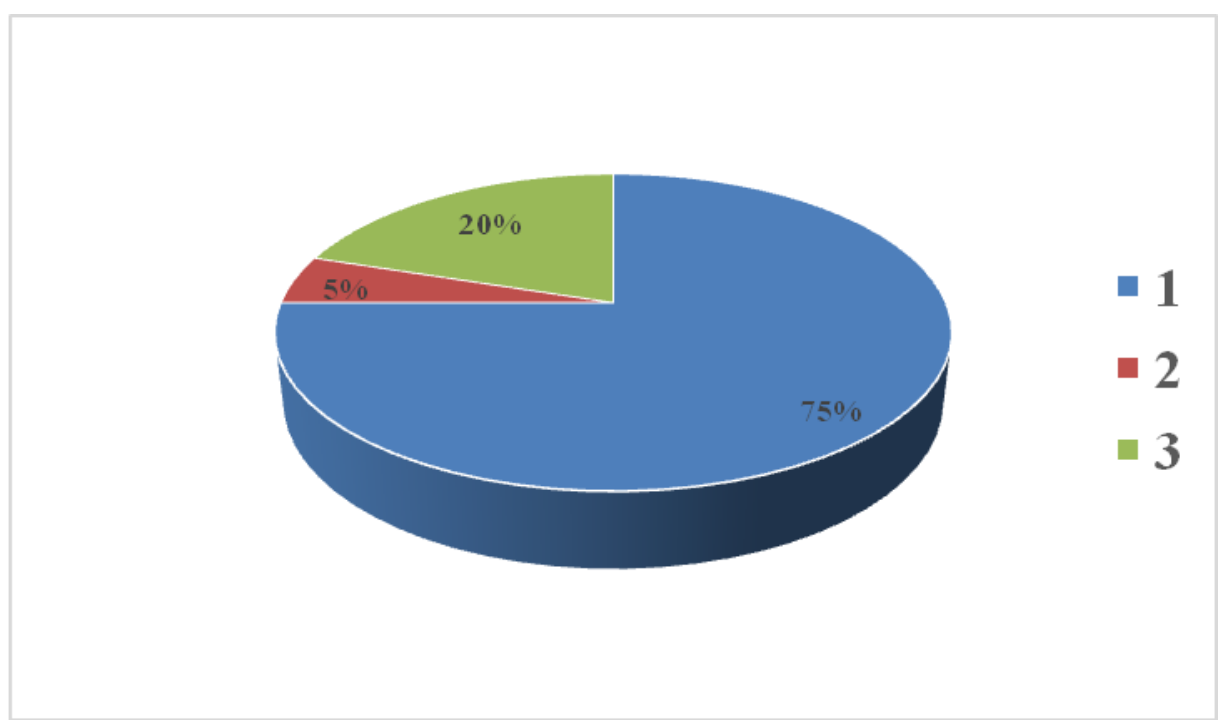

Figure 3: Farmers opinion on pregnancy detection

$1=$ Detect animal on heat and successful conception

$2=$ Detect pregnancy by change in behavior of the animal after successful conception

$3=$ Detect pregnancy from late second trimester

\section{DISCUSSION AND RECOMMENDATION}

The weight parameters showed significant difference across the column from group 1-5 $(\mathrm{p}<0.05)$ except between group 6 and 7. No significant difference was seen in the CVRL from group 1-5, however, they differ from group 6 and 7 . The CVRL of the $1^{\text {st }}, 2^{\text {nd }}$ and $3^{\text {rd }}$ trimesters shows that no significant difference $(\mathrm{p}<0.05)$ exist between $2^{\text {nd }}$ and $3^{\text {rd }}$ trimesters, but they differ significantly from $1^{\text {st }}$ trimester. Furthermore, for the body weight, significant differences $(\mathrm{p}<0.05)$ was seen across the three trimesters.

The result obtained on methods of detecting pregnancy by the farmers showed that 10 (20\%) of farmers could detect pregnancy by behavioral changes of the animal after successful conception. However, if accuracy of the observation could be ascertained, this probably would be the least expensive method of pregnancy diagnosis in the first trimester. Other farmers, $38(75 \%)$ of the total respondents could detect pregnancy from late second trimester. The remaining $3(5 \%)$ respondents had the ability to detect estrus in their farms, which is an asset in pregnancy 
diagnosis as suggested by Arthur (1975). Abdominal palpation, change in shape and weight and mammary gland development of the animal were some of the methods used by the farmers to detect pregnancy in advanced stages. These are similar to the methods of Arthur (1975) and Maxine (2006).

\section{Recommendation}

Facilities for detecting pregnancy should be installed in the abattoir and record of the date of conception should always be noted by farmers.

\section{CONCLUSION}

Generally, this result showed that body weight and CVRL increases with age and 5\%,20\% and $75 \%$ of the farmers can detect animal on heat and successful conception, detect pregnancy by change in behaviour of the animal after successful conception and detect pregnancy from late second trimester respectively.

\section{REFERENCE}

Adelana, S.M.A., Olashinde, P.I. and Vrbka, P. (2003). Isotope and geochemical characteristic of surface waters in the Semi-arid Sokoto Basin, Nigeria. African Journal of Science and Technology 4(2):80-89.

Arthur, G.H. (1975). Veterinary Reproduction and Obstetrics $4^{\text {th }}$ ed. Barllierc Tindull London. p35

Davendra, C. and Mcleroy, G.B. (1982). Reproductive behavior. Goat and sheep production in the tropics. Longman group Ltd, London p27.

FOS (Federal Office of Statistics). (1986). Annual abstract of statistics FOS. Lagos. Nigeria. p202.

Maigandi, S.A., Tukur, H.M. and Suleiman, A. (2001). Post-weaning performance of Sokoto Red Goat Kids Under Traditional Management System in Sokoto State, Nigeria. Sokoto Journal of Veterinary Sciences. Vol. 3(2):36-39.

Maxine, K. (2006). Pregnancy Diagnosis Techniques. In: Pregnancy diagnosis in Pygmy goats. http://kinne.net/pregdiag.htm

Nwaogu, I.C. and Okolie S.A. (2006). Studies on morphological features of fetal and adult ovaries in Kano Brown Goat. Book of Abstract of the $43^{\text {rd }}$ Annual Congress of the Nigerian Veterinary Medical Association (NVMA) Mina 2006 p40

Oni, O.O. (2002). Breeds and Genetic Improvement of small ruminants (sheep and goats). Manual for small ruminant production in Nigeria. Compilation for a training workshop on small ruminant production held at the National Animal Production Research Institute, Zaria, Nigeria $13^{\text {th }}$ to $18^{\text {th }}$ January, 2002 Pp27 Animal Science Journal 74: 195-203. 
Osuagwuh, A.I.A. (1985). Incidence and control of pre-weaning mortality and abortion in small ruminants. In small ruminant production in Nigeria. Proceedings of national conference on small ruminant production held at Zaria from $6^{\text {th }}-10^{\text {th }}$ October, 1985 NAPRI, ABU, Zaria, Nigeria.

Ryder, M. (1984). Sheep In: Evolution of Domesticated Animals (Mason, I.L.ed), Longman, London Pp33-85.

Umar, A.A., Kwari, H.D. and Garba, H.S. (2006). Feotal loss due to slaughter of pregnant Red Sokoto does.Dange Shuni Sokoto Nigeria. Book of Abstract of the $43^{\text {rd }}$ Annual Congress of the Nigerian Veterinary Medical Association (NVMA) Minna, 2006 p11 